\title{
Investigation of shallow landslides triggered by heavy rainfall during typhoon Wipha (2013), Izu Oshima Island, Japan
}

\author{
Hufeng Yang ${ }^{1 *}$, Fawu Wang ${ }^{1}$ and Masakatsu Miyajima ${ }^{2}$
}

\begin{abstract}
Background: Typhoon Wipha struck Izu Oshima Island on 16 October 2013, bringing heavy rainfall. It triggered widespread landslides on the western slopes of Izu Oshima Island, and caused significant loss of life and serious property damage. Authors have conducted both field investigations and laboratory experiments in an effort to understand the initiation mechanism of the shallow landslides triggered by heavy rainfall.

Results: Pyroclastic-fall deposits on the slopes are well-graded fine sand with silt, and with high specific gravity and void ratio. These soil properties will affect the mechanical and hydraulic characteristics of soil. The results of consolidated-undrained triaxial tests show that the effective internal friction angle of soil is 38.7 degrees. The results of triaxial tests using pore-water pressure control show that static liquefaction can occur in porous pyroclastic-fall deposit layers due to rainfall infiltration.

Conclusions: The effective strength of pyroclastic-fall deposits on the upper slope is quite high. Even though the slope is very steep (over 30 degrees), it can remain stable while in an unsaturated condition. Due to heavy rainfall and the porosity of the pyroclastic-fall deposits, rainfall can quickly infiltrate into soil layer. Moreover, the interface above the underlying basalt will stop groundwater infiltration, acting as an impervious boundary. With increase of groundwater level, the effective strength of the porous soil will decrease. Finally, static liquefaction can be triggered, leading to the generation of shallow landslides on the upper slopes.
\end{abstract}

Keywords: Shallow landslide; Rainfall; Triaxial test; Initiation mechanism; Izu Oshima Island

\section{Background}

Typhoon Wipha passed the Izu Islands on 16 October 2013. These islands are located at the southeast of the Izu Peninsula, Japan (Fig. 1). Most regions on the typhoon track, especially the Izu Oshima Island, suffered heavy rainfall. It triggered widespread shallow landslides on the western slopes of Izu Oshima Island (Fig. 2). Pyroclastic-fall deposits mixed with branches and trunks flowed downslope along gullies and drainage channels. High speed debris flows flooded the settlement of Motomachi, which is situated at the toe of the slopes. This disaster caused serious loss of life and property damage. According to the damage report, 35 people

\footnotetext{
* Correspondence: yanghufeng@gmail.com

'Department of Geoscience, Shimane University, Matsue 690-8504, Japan

Full list of author information is available at the end of the article
}

were killed, four people remain missing, 73 houses were completely destroyed, and 129 houses were damaged (Ministry of Land Infrastructure and Transport and Japan 2013).

Several researchers and organizations carried out field investigations after this geo-disaster event (Sakurai and Disaster Research Team of Kanto Branch 2014; Ikeya 2014; Disaster Prevention Division of Tokyo Metropolitan Government (TMG) (2014)). Their investigation reports describe the occurrences of the landslides, and the damage caused by the debris flows. These studies provide key background information for further research. Authors had conducted both field investigations and laboratory experiments in an effort to understand the initiation mechanism of shallow landslides triggered by heavy rainfall during $\mathrm{Ty}-$ phoon Wipha. Consolidated-undrained triaxial tests were 


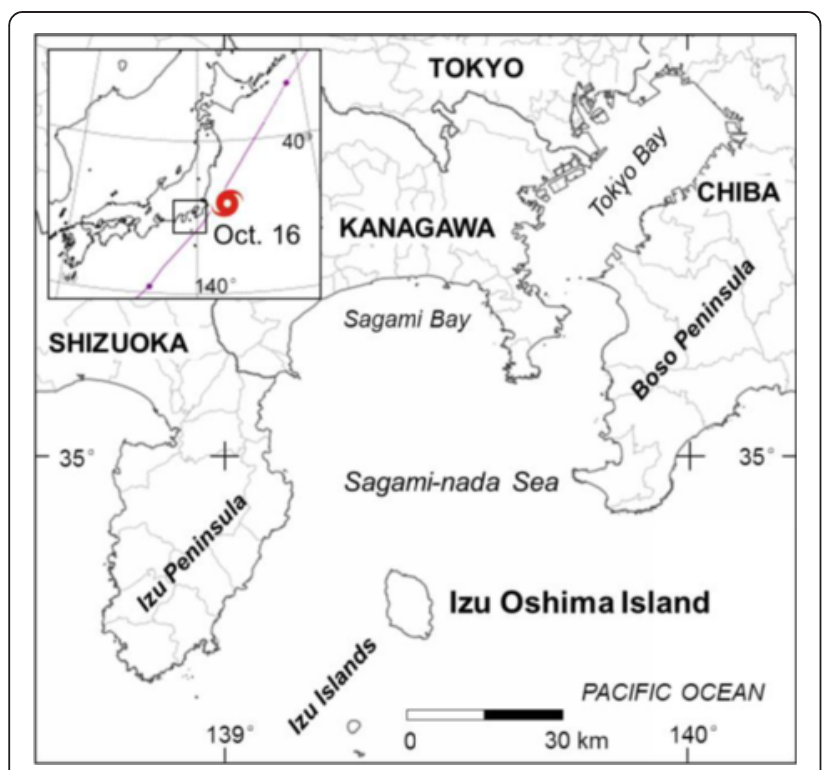

Fig. 1 Location of Izu Oshima Island. Inset is the track of Typhoon Wipha

conducted to determine the effective soil strength. This paper also presents the results of triaxial tests with porewater pressure control, which were conducted to simulate the initiation mechanism of the shallow landslides on the upper slopes due to rainfall infiltration.

\section{Study site}

\section{Geology}

Izu Oshima Island is a volcanic island. This active volcano consists of pre-caldera, syn-caldera and post-caldera volcanoes (Kawanabe 1998). Many hazardous eruptions have occurred in the past. The ejecta in each stage were mostly coarse-grained pyroclastic materials, with basaltic lava flows and pyroclastic-fall deposits. Younger deposits and lava flows covered the deposits and lava flows from the older volcano stage. This type of volcanic activity led to the formation of resistant lava flows interbedded with poorly consolidated pyroclastic-fall deposits. Fig. 3 shows the geological map of the main landslide area, which is outlined in Fig. 2 (right) with a yellow frame. Most of the shallow landslides which were the source of the debris flows occurred within the distribution of basalt (Y5L). Pyroclastic-fall deposits overlie the basalt (Y5L) in the section which is exposed in the upper slope along the road (Fig. 4). This type of structure with interbedded resistant basalt and weak pyroclastic deposits can easily cause landslides. Moreover, the interface between these two layers tends to be a confining boundary for groundwater passing through the upper soft and porous pyroclastic-fall deposits.

\section{Topography}

The topography of Izu Oshima Island is typical of a volcanic island. The outline of the island is oval, elongated

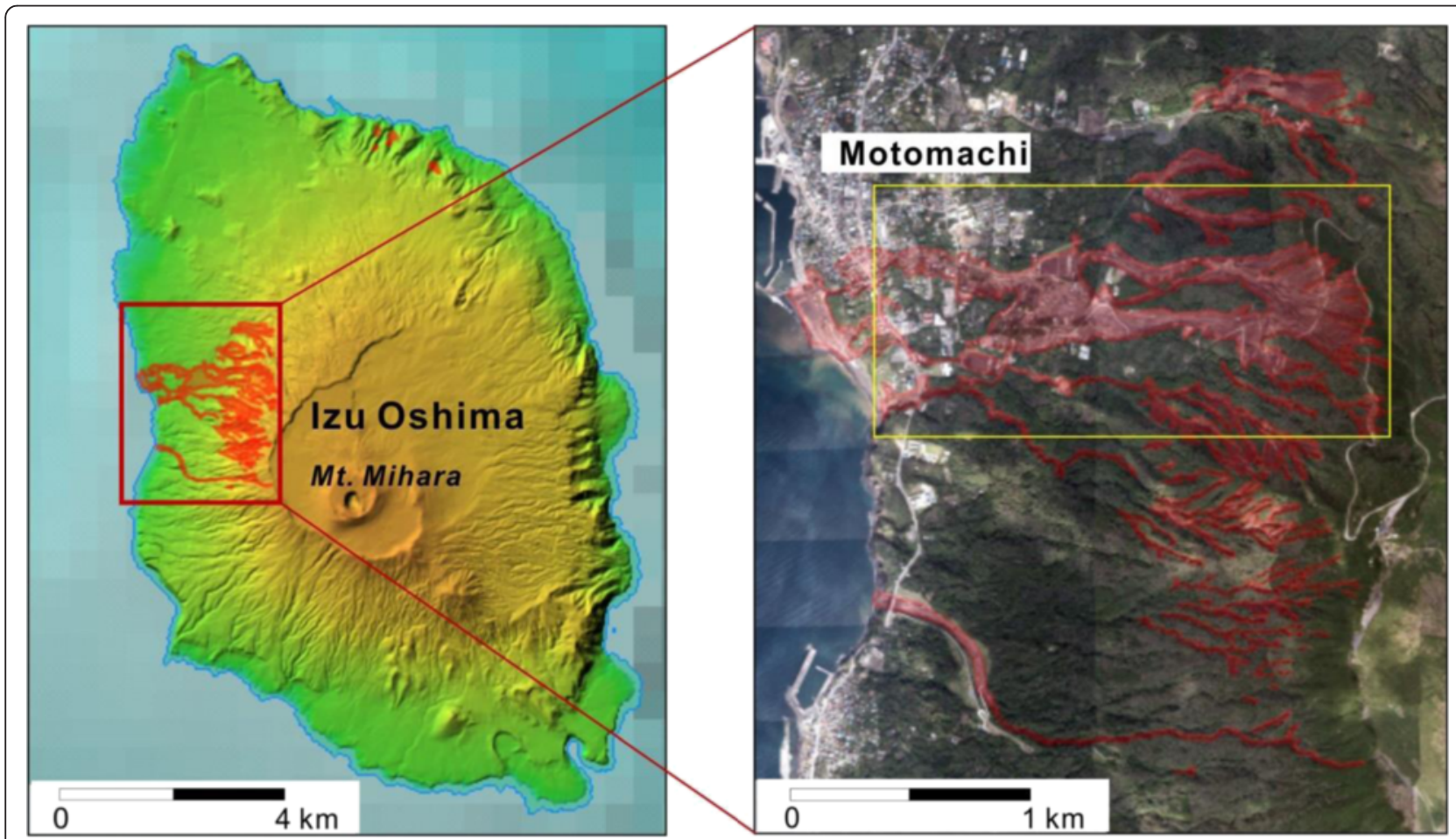

Fig. 2 Landslides in the west of Izu Oshima Island (red areas indicate the landslide distribution, modified from Geospatial Information Authority of Japan, 2013) 


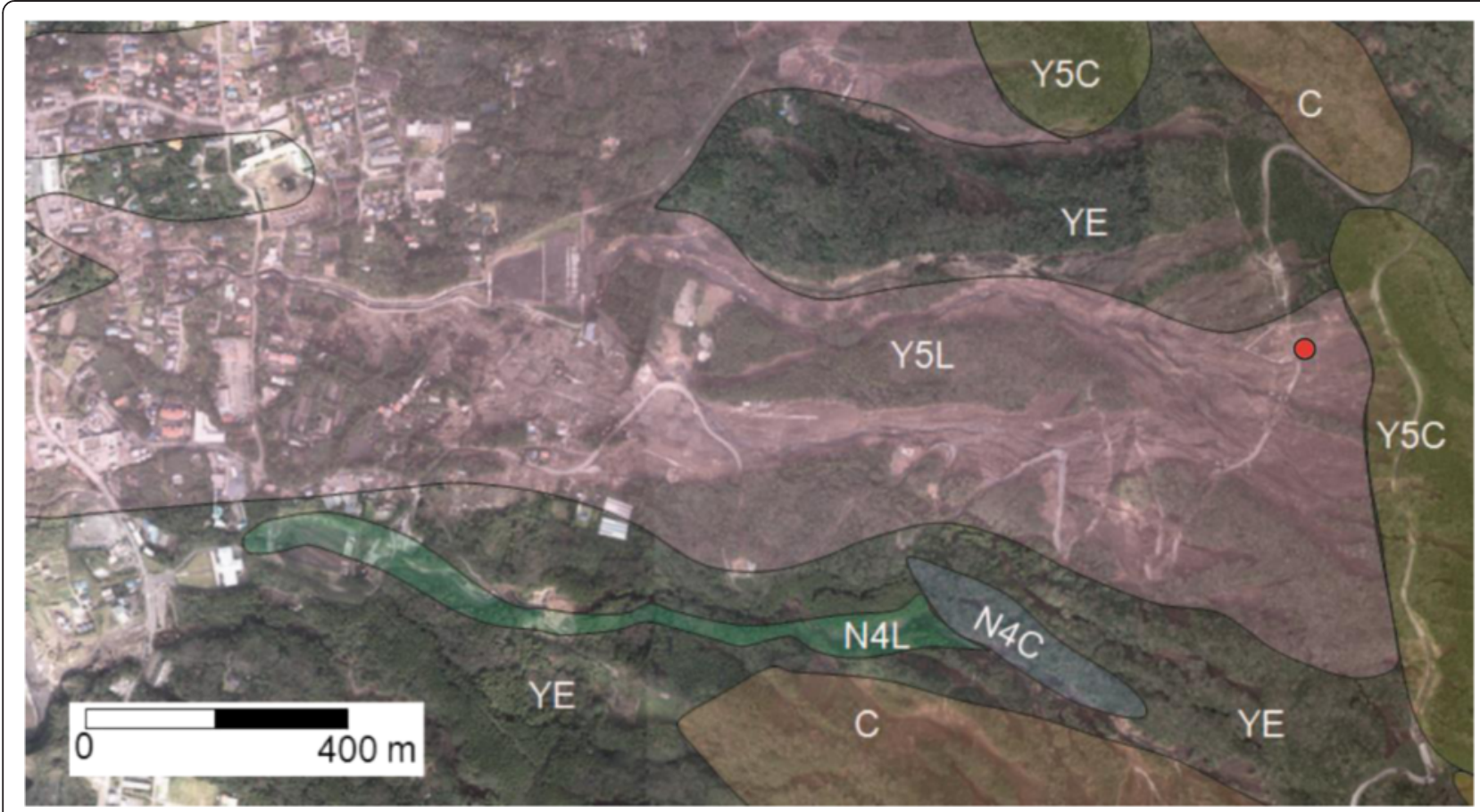

Fig. 3 Geological map of main landslide area (modified from Kawanabe 1998; photograph from the Geospatial Information Authority of Japan). Y5L: Basalt (Syn- and post-caldera volcano, 1338?); Y5C: Basalt scoria and spatter (Syn- and post-caldera volcano, 1338?); N4L: Basalt (Syn- and post-caldera volcano, 8th Century); N4C: Basalt scoria (Syn- and post-caldera volcano, 8th Century); C: Basalt scoria (Pre-caldera volcano); YE: Pyroclastic-fall deposits (Pre-caldera volcano)

in the NNW-SSE direction, with a length of about $15 \mathrm{~km}$, and width of about $9 \mathrm{~km}$ (Kawanabe 1998). The central part of the island has the highest elevation due to volcano eruption. The highest point is Mt. Mihara (764 $\mathrm{m}$ a.s.l.), and the terrain becomes gentler towards the coast. Sea cliffs up to $350 \mathrm{~m}$ high are developed from the north to the east, and in the southwest of the island, due to wave erosion. The highest cliff is found on the east coast. Relatively flat land in the northwest of the

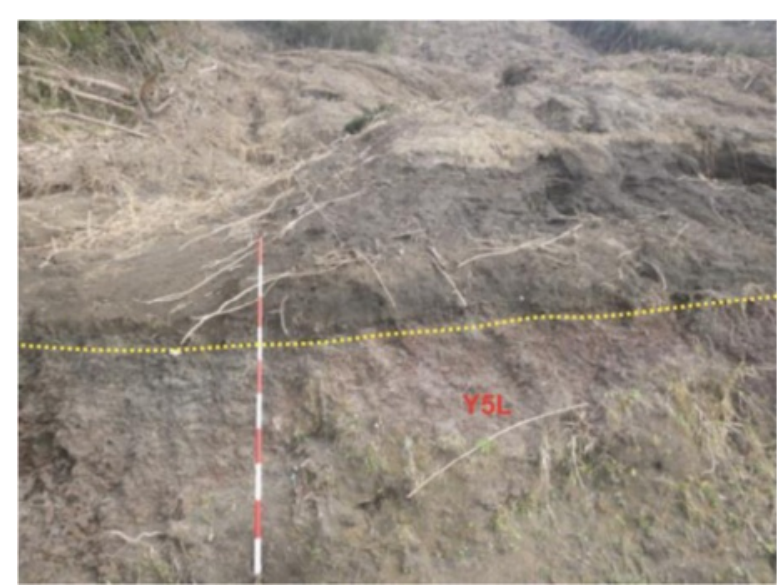

Fig. 4 Basalt (Y5L) overlain by pyroclastic-fall deposits (at red spot in Figure 3) island was planned as a residential area. A caldera with a diameter of about $4 \mathrm{~km}$ is present at the summit of the volcano, but in the east its wall is buried by younger lava. On the west side, the caldera wall is clearly defined. In addition, the slopes of the outer rim of the western caldera wall are quite steep (Fig. 5). Most of the shallow landsides occurred on the steep slopes.

\section{Heavy rainfall}

The main triggering factor of these shallow landslides was the short-period downpour of heavy rainfall. On the early morning of 16 October 2013 Typhoon Wipha was close to the Izu Islands (Fig. 1). As Typhoon Wipha approached, the northern Izu Islands suffered heavy rainfall, especially Izu Oshima Island. Records from the meteorological station at Motomachi in the Izu Oshima Island show the maximum one-hour precipitation was about $118.5 \mathrm{~mm}$. The maximum 24-hour accumulated precipitation was more than $824 \mathrm{~mm}$ (Fig. 6). This was 2.5 times the average monthly precipitation for October in Izu Oshima Island (Tokyo District Meteorological Observatory (TDMO) 2013).

\section{Field investigation}

Fig. 7 shows a plan view of the areas that were impacted by debris flows. According to the information from local residents and seismic data, shallow landslides (light blue 


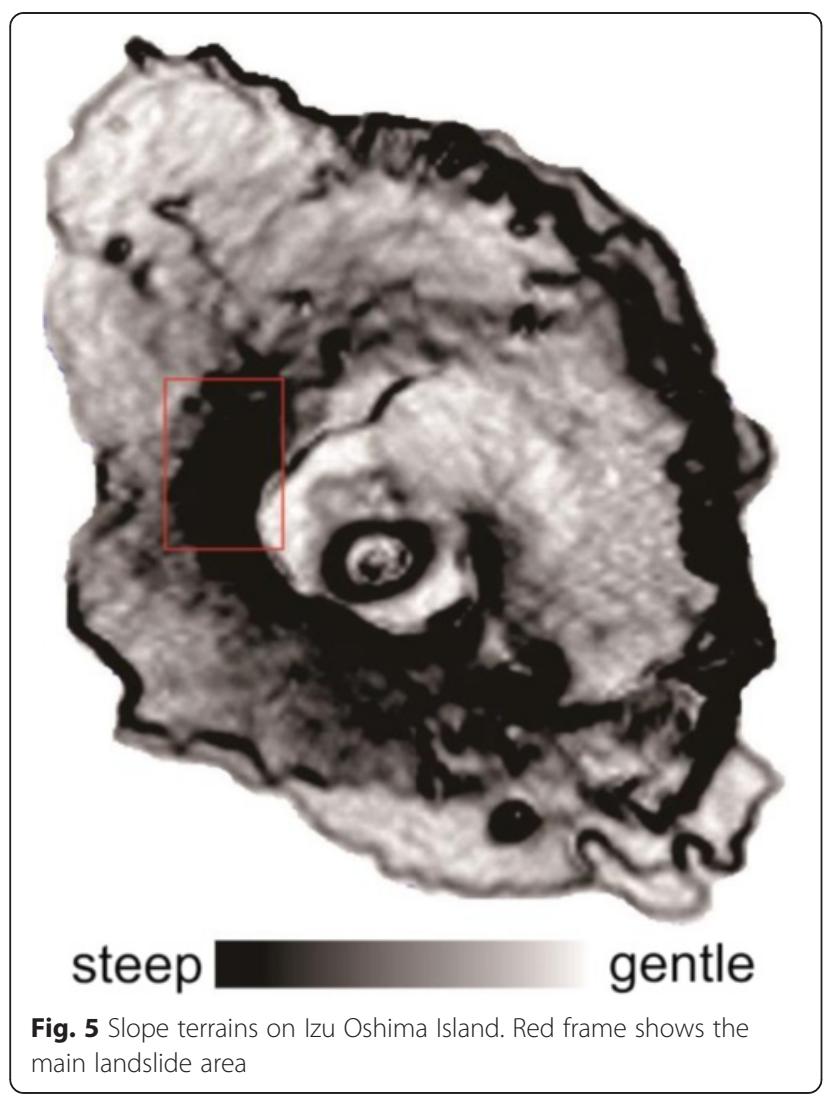

area) occurred on the upper slopes in the early morning (Ikeya 2014). Pyroclastic-fall deposits mixed with branches and trunks flowed downslope along the gullies (beige arrows). Debris flow flushed away the surface soil and vegetation along the gullies (gullies A and B in Fig. 7). Because no drainage channels were present, the debris flow flooded the houses situated on the down slopes area (light red area), and caused serious loss of lives and properties. The sabo dam 1 , which is located at the mouth of gully A, played an important role in protecting this area. It effectively reduced the speed of the debris flow, and captured branches and trunks. Furthermore, fine-grained particles were easily drained out through the drainage channel (brown arrow) (P2 in Fig. 8). Finally, this fine material flowed into the ocean and was deposited at the coast (P3 in Fig. 8). Sabo dam 2, situated just behind the Volcano Museum, stopped the debris from damaging the museum and nearby residential houses.

Shallow landslides on the upper slopes which were the source of debris flows were examined in the main investigation area (Fig. 9). Slope angle is one of the most important factors on slope instability. In the field, Laser Range Finder (LRF) was used to survey the longitudinal profile (A-A' in Fig. 9) of the shallow landslide selected for study. The measuring result shows that slope is with steep terrain, and slope angle is over 30 degrees.

\section{Methods}

Soil samples were collected from the pyroclastic-fall deposit layer above the basalt at location S1 to study soil properties (Fig. 9). Conventional laboratory experiments on the soil sample were conducted to obtain the basic parameters (grain size distribution, specific gravity, insitu dry density and void ratio) which will be used to control the parameters of specimens for triaxial tests.

\section{Triaxial text using strain control}

Consolidated-undrained triaxial tests were conducted to determine the effective soil strength. According to the in-situ soil dry density, dry soil passed $2 \mathrm{~mm}$ sieving was used to make a cylindrical specimen. In order to get a homogenous specimen, the dry soil sample was divided into several parts to fill the cylindrical specimen tube with rubber membrane. After filled the all soil into the specimen tube, the cylindrical surface of the sample is covered by the rubber membrane sealed by rubber O-rings on the top and base of load system. After that, the specimen was fully saturated. Carbon dioxide $\left(\mathrm{CO}_{2}\right)$ was slowly supplied from the base of the specimen to gradually replace the air within it. Then de-aired water was slowly supplied to replace and absorb the $\mathrm{CO}_{2}$ to achieve a saturated state. The specimen was confirmed to be fully saturated when the Skempton's B value, which is

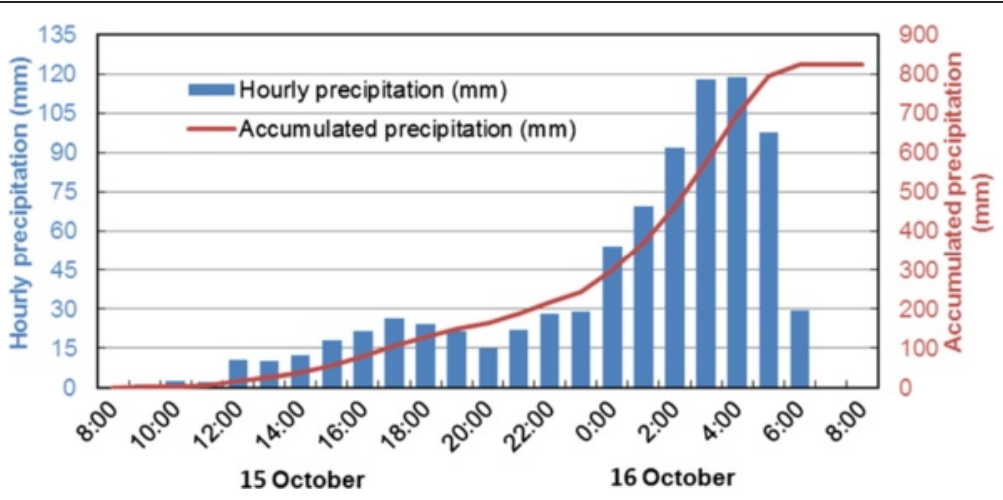

Fig. 6 Hourly and accumulated precipitation in Izu Oshima Island from 15 October (8:00 a.m.) to 16 October (8:00 a.m.) 2013 


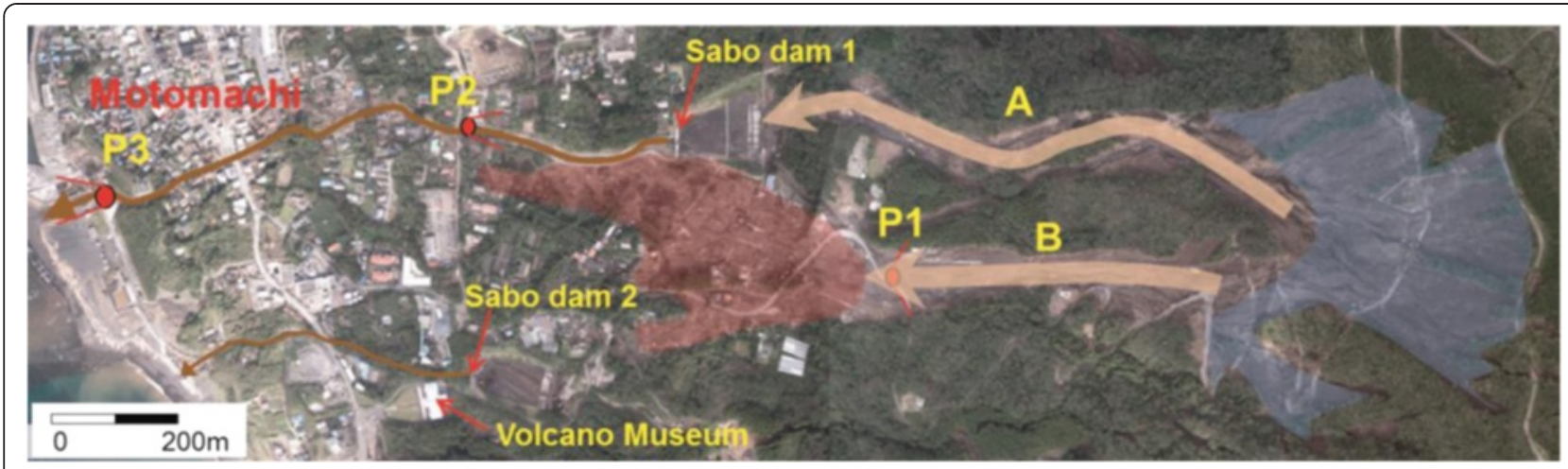

Fig. 7 Plan view of the main landslide area (photograph from the Geospatial Information Authority of Japan)

called pore-pressure coefficients (Skempton 1954), was higher than 0.95. With the fully saturated specimens, four consolidated-undrained compression tests were conducted under four different confining stresses (25, 50, 75 and 100 $\mathrm{kPa}$ ). After normal consolidation, the specimens were compressed at $1.0 \%$ of axial strain per minute under the undrained condition. The data of deviatoric stress, pore-water pressure and axial strain was obtained by data logging system. Through these tests, the shear strength parameters can be obtained.

\section{Triaxial text using pore-water pressure control}

Triaxial tests with pore-water pressure control were conducted to simulate the initiation mechanism of the shallow landslide on the upper slopes due to rainfall infiltration.

The thickness of the upper layer soil varies from 1 to 3 meters, and hence for the initial stress condition the major principal stress can be assumed to be $40 \mathrm{kPa}$, based on the unit weight of the soil. The minor principal stress can be obtained as $15 \mathrm{kPa}$, based on the lateral earth pressure coefficient $\left(K_{0}\right)$, which can be calculated using Equation (1).

$$
K_{0}=1-\sin \phi^{\prime}
$$

where $\phi^{\prime}$ is effective friction angle of the soil.

The process of specimen preparation and saturation was the same as that of the triaxial tests using strain control. The confining pressures were $\sigma_{1}=40 \mathrm{kPa}$ and $\sigma_{3}=15 \mathrm{kPa}$. After consolidation, de-aired water is supplied through a pore-water pressure controller to increase the pore-water pressure. The rate of increase in pore-water pressure was $0.2 \mathrm{kPa}$ per minute. Through this step, the situation of pore-water pressure accumulation on the potential sliding surface is simulated.
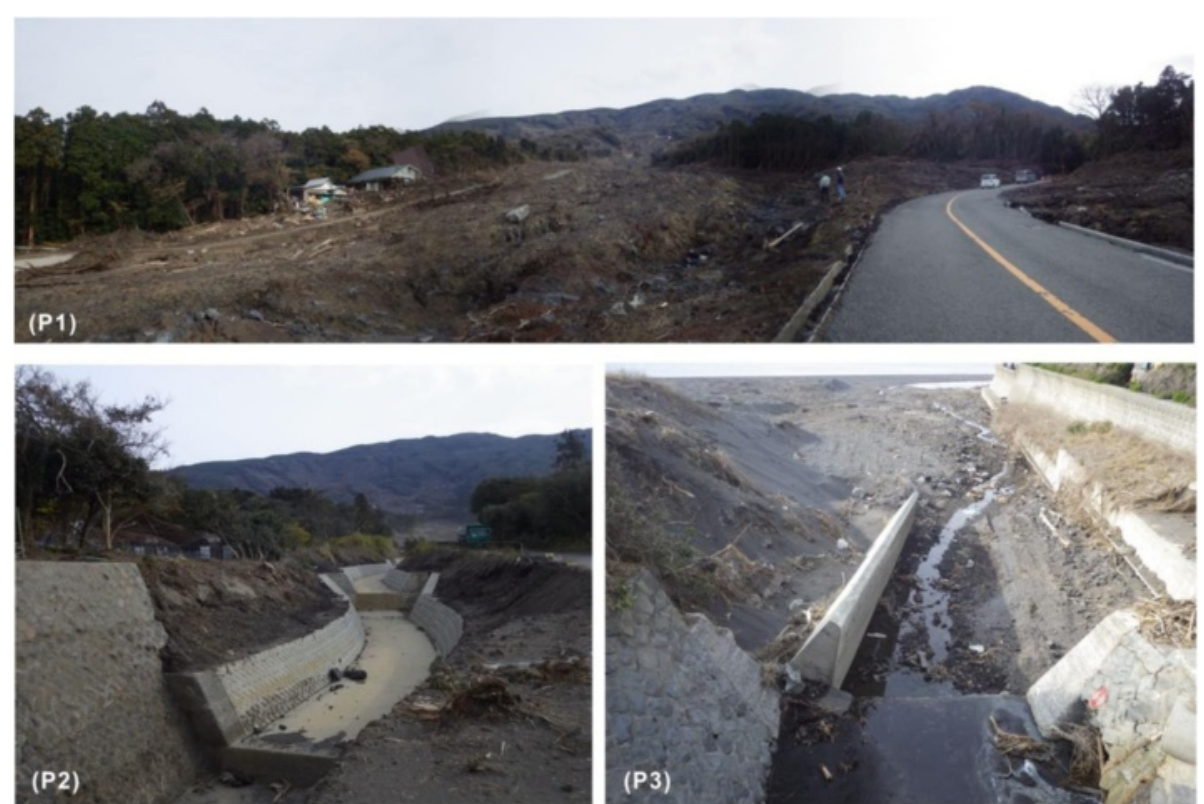

Fig. 8 Photograph locations are marked on Figure 7 


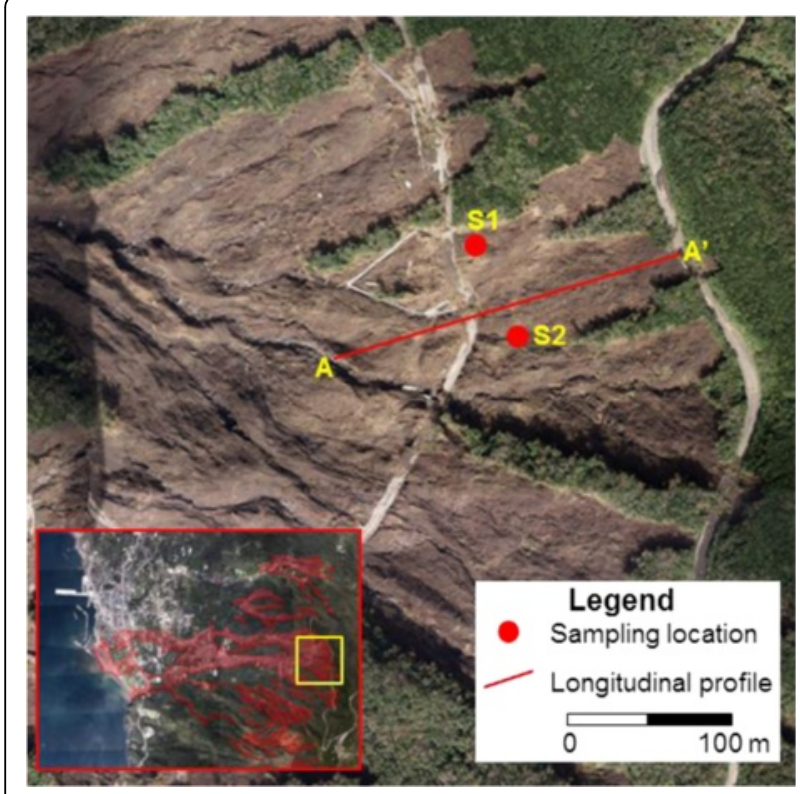

Fig. 9 Main investigation area of the shallow landslides on the upper slopes (photographs from the Geospatial Information Authority of Japan)

\section{Results}

In the Table 1, it can be observed that the specific gravity and void ratio of the pyroclastic-fall deposits are 2.903 and 1.183 , respectively. That shows the typical property of pyroclastic-fall deposits. These soil properties will affect the mechanical and hydraulic characteristics of the soil. Grain size distribution of sample shows that the soil is well-graded fine sand with silt (ASTM D2487-06 2006). After the occurrence of shallow landslides, these fine materials on steep slopes can easily transform into debris flow during heavy rainfall.

The stress-strain relationship of the consolidatedundrained tests on the saturated specimens (Fig. 10a) shows that the deviatoric stress increases with the axial strain. The stress-strain curves indicate the evidence of strain hardening. When the shear strain is over about $15 \%$, the deviatoric stress begins to flatten. Critical state was reached in all four tests with a high axial strain. The relationship between the excess pore-water pressure and the axial strain of the consolidated-undrained tests on the

Table 1 Soil parameters

\begin{tabular}{ll}
\hline Parameters & Value \\
\hline Specific gravity, $G_{s}$ & 2.903 \\
Coefficient of uniformity, $C_{u}$ & 12.188 \\
Coefficient of curvature, $C_{c}$ & 1.154 \\
Mean grain size, $D_{50}(\mathrm{~mm})$ & 0.143 \\
Dry density, $\rho_{d}\left(\mathrm{~kg} / \mathrm{m}^{3}\right)$ & 1,330 \\
Void ratio, $e$ & 1.183 \\
\hline
\end{tabular}

saturated specimens is shown in Figure 10b. Positive excess pore-water pressure was recorded in all four tests. In all tests, the positive excess pore-water pressure increases to a peak at low strain (about $5 \%$ ), reduces from its maximum value as the strain increases continuously, and finally reaches a steady state at the end of the tests. The initial buildup of the positive excess pore-water pressure suggests that the specimens exhibit contractive behavior. The reduction in the excess pore-water pressure after the peak indicates that the specimens change from contractive to dilative behavior during shear, as illustrated by the effective stress paths shown in Fig. 11. Ng and Chiu (2001) described the similar shear behaver of loosely compacted saturated volcanic soil under undrained conditions in their paper. All the effective stress paths show a similar trend. Each path moves toward the right-hand side initially, and then moves toward the left-hand until reaching a turning point, after which they turn right, before reaching the critical state line CSL at the end of the test. The critical states of saturated specimens can be represented by the CSL in the stress plane, as shown in Fig. 11. The gradient of the critical state line is 0.625 . This corresponds to a critical state angle of internal friction angle of 38.7 degrees.

The relationships between deviatoric stress, axial strain and pore-water pressure under loose and dense conditions are shown in Fig. 12a and b, respectively. For the soil in loose condition (initial void ratio of 1.079), effective stress starts to decrease when the pore-water pressure increases to about $8 \mathrm{kPa}$. Obvious decrease of effective stress is generated when the pore-water pressure reaches about $12 \mathrm{kPa}$. Excess pore-water pressure builds up with rapid increase of axial strain. For the dense condition (initial void ratio of 0.808), effective stress starts to decrease when pore water pressure increases to about $13 \mathrm{kPa}$. Obvious decrease of effective stress is generated when the pore-water pressure reaches about $17 \mathrm{kPa}$. In contrast to the loose condition, the rate of increase of pore-water pressure slows with the rapid increase in axial strain. From these results, it is evident that obvious decrease of effective stress occurs in a shorter time in the soil in loose condition than it is in dense condition.

\section{Discussion}

\section{Two types of failure mode}

Two types of failure mode can be proposed, based on the pattern of shallow landslides on the steep slopes along the road (Fig. 13). The first type of failure mode shows that pyroclastic-fall deposits partially mantling the upper most slopes slid first, during heavy rainfall. The soil mass then crossed the road, and drove the pyroclastic-fall deposits lying below the subgrade, to slide downslope together. For this type of failure mode slope cutting during road construction affects the stability of the pyroclastic-fall deposits on the upper 

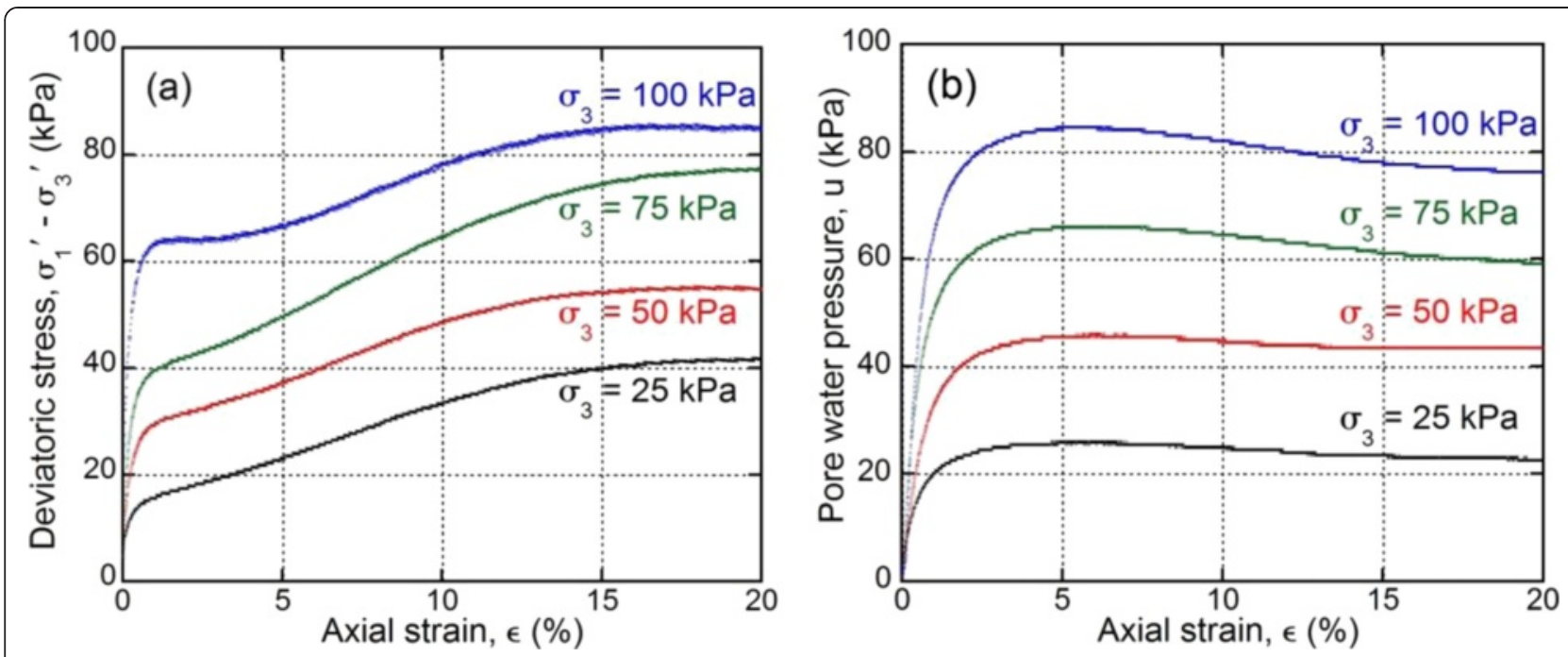

Fig. 10 (a) stress-strain relationship; (b) relationship between pore-water pressure and axial strain for the consolidated-undrained tests

slopes. Slope cutting without any preventive construction will result in a free boundary, and remove the resistance at the toe of slope. Therefore, the slope can easily become unstable under trigger factors such as rainfall and dynamic load.

The second type of failure mode shows that the entire pyroclastic-fall deposits below the road started to slide during heavy rainfall. The main scarp of this shallow landslide was located at the subgrade of the upper part of the road. The topographic map shows that the section of subgrade of the upper road near the main scarp was of relatively low elevation (Fig. 14). The lower-lying and winding road surface will collect surface water during heavy rainfall. Subsequently, runoff water will continuously infiltrate the pyroclastic-fall deposit layer on the slope below the road subgrade. Finally, groundwater increase in the slope will lead to the pyroclastic-fall deposits sliding.

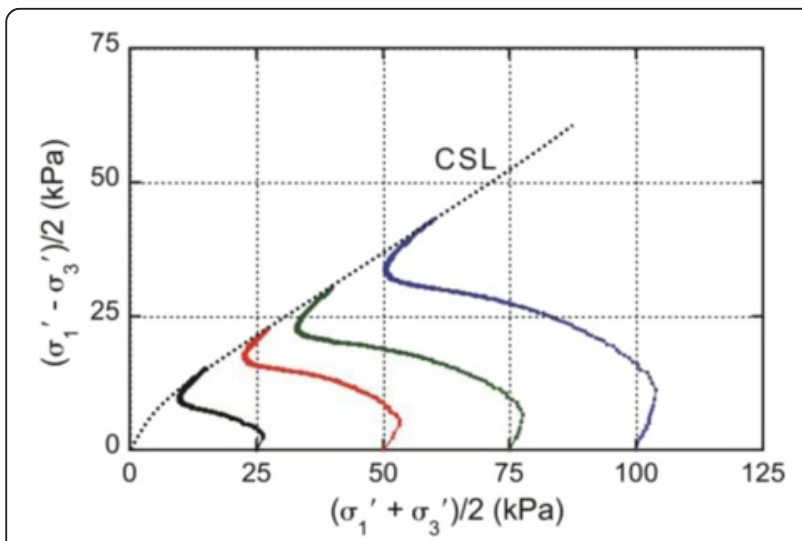

Fig. 11 Effective stress paths under different confining pressures $(25,50,75$ and $100 \mathrm{kPa}) ; \mathrm{CSL}$ - Critical State Line

\section{Slope angle}

According to historical literature, landslide disasters caused by heavy rainfall have occurred several times on the slopes near Motomachi (National Research Institute for Earth Science and Disaster Prevention (NIED) 2013; Sakurai 2014). From the slope angle distribution of the Izu Oshima Island (Fig. 5), it is evident that the slopes where landslides have often occurred are quite steep. To discuss the effect of slope angle on the slope stability, a simplified slope model for limit equilibrium analysis can be assumed (Fig. 15) based on the slope structure.

For the unit width, the factor of safety $\left(F_{S}\right)$ of slope can be obtained using Equation (2).

$$
F_{S}=\frac{c^{\prime}+\left(\gamma H-\gamma_{w} h\right) \cos ^{2} \alpha \tan \phi^{\prime}}{\gamma H \sin \alpha \cos \alpha}
$$

where,

$H$ is the thickness of the pyroclastic-fall deposit layer;

$h$ is the height of groundwater table;

$\alpha$ is the slope angle;

$\gamma$ is the average unit weight of soil, $17 \mathrm{kN} / \mathrm{m}^{3}$;

$\gamma_{w}$ is the unit weight of water, $9.8 \mathrm{kN} / \mathrm{m}^{3}$;

$c^{\prime}$ is the effective cohesion of soil;

$\phi^{\prime}$ is the effective friction angle of soil, 38.7 degrees.

Due to that, the pyroclastic-fall deposits can be considered as a cohesionless soil Equation (2) can be simplified as follows:

$$
F_{S}=\left(1-\frac{\gamma_{w}}{\gamma} \cdot \frac{h}{H}\right) \frac{\tan \phi^{\prime}}{\tan \alpha}
$$

For the slope without rainfall infiltration, and in which there is no obvious groundwater table, $h$ in Equation (3) can be assumed to be 0 . Therefore, the relationship between factor of safety and slope angle can be plotted as 


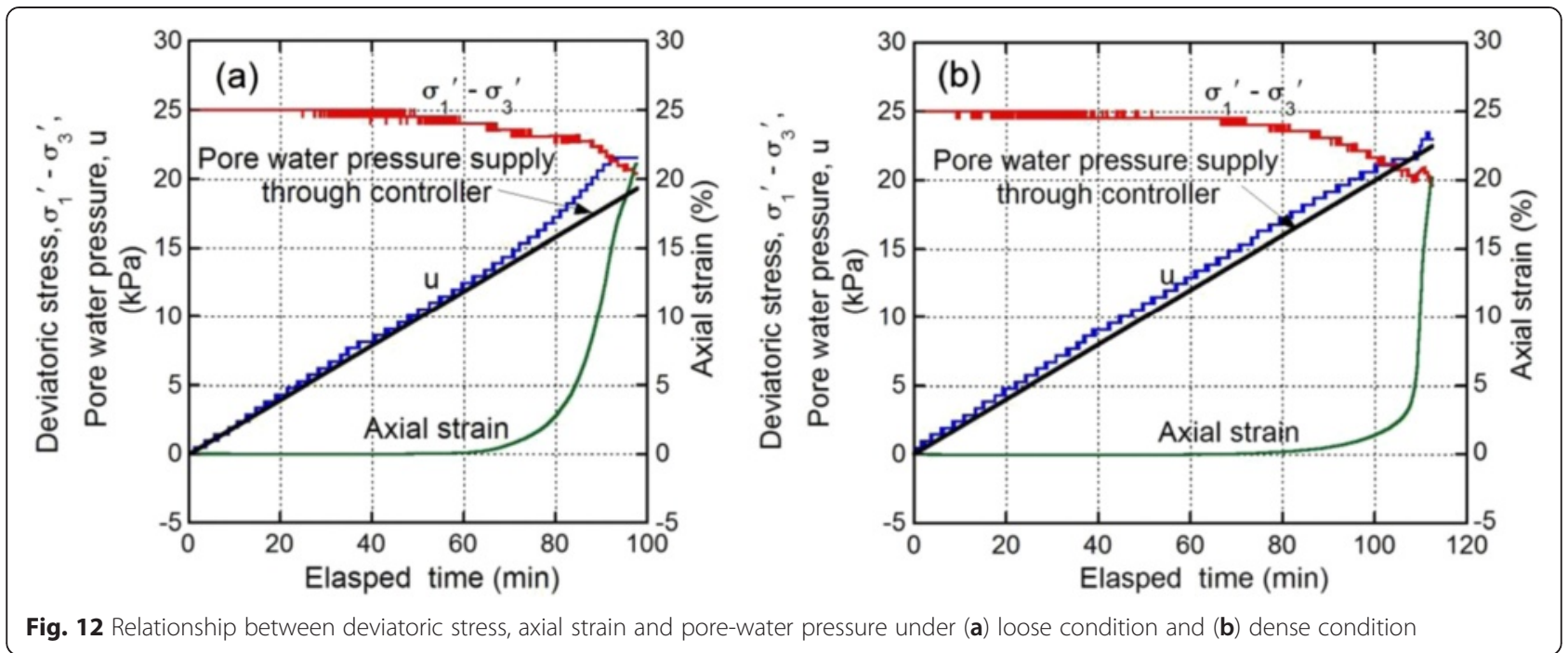

in Fig. 16. This result shows that slope will remain stable, even if the slope angle is steep as 38 degrees.

Due to rainfall infiltration during heavy rainfall, the groundwater table in the slope will increase gradually, and this will affect the slope stability. Taking a slope with a two-meter thick pyroclastic-fall deposit layer as an example, we can plot the relationship of factor of safety $\left(F_{S}\right)$ with the height of the groundwater table and slope angle, using Equation (3) (Fig. 17). From this figure, it is apparent that relatively gentle slopes (such as

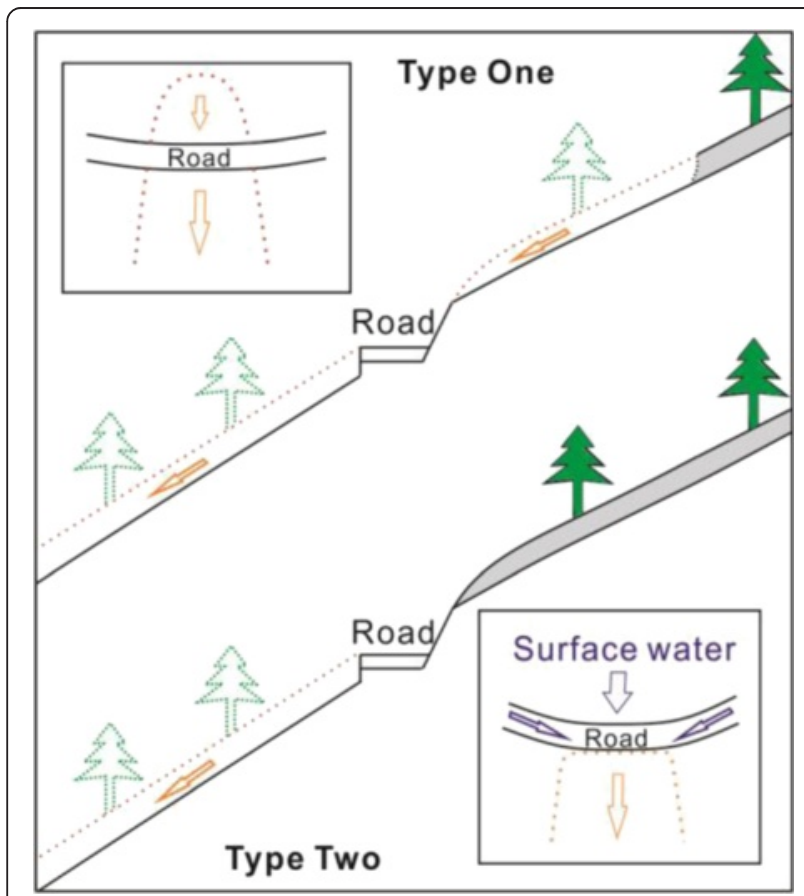

Fig. 13 Two types of failure mode of shallow landslides
20 degrees) can remain stable even when the height of groundwater table nearly reaches the ground surface. However, relatively steep slopes (such as 30 degrees) will reach a critical situation when the groundwater table reaches half the thickness of the pyroclastic-fall deposit layer.

\section{Static liquefaction}

The profile of the pyroclastic-fall deposits on the slope (Fig. 18) shows that several obvious layers are present. Layer 1 is surface soil, mixed with plant roots. Layer 2 and Layer 4 are both yellowish-brown deposits with a tough and cemented structure. Their yellow color originates from abundance of fine clay particles. Therefore, the permeability of these layers is quite

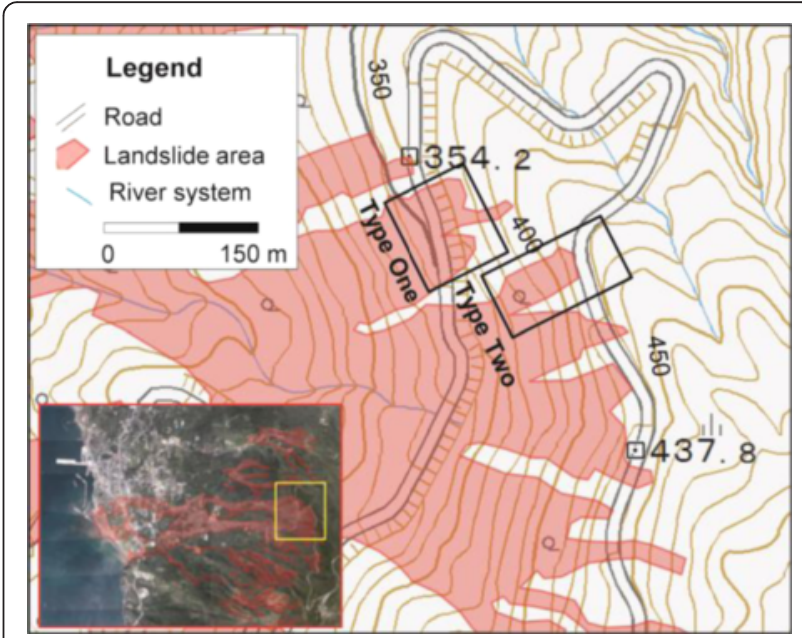

Fig. 14 Topographic map of the upper slope (modified from Geospatial Information Authority of Japan) 


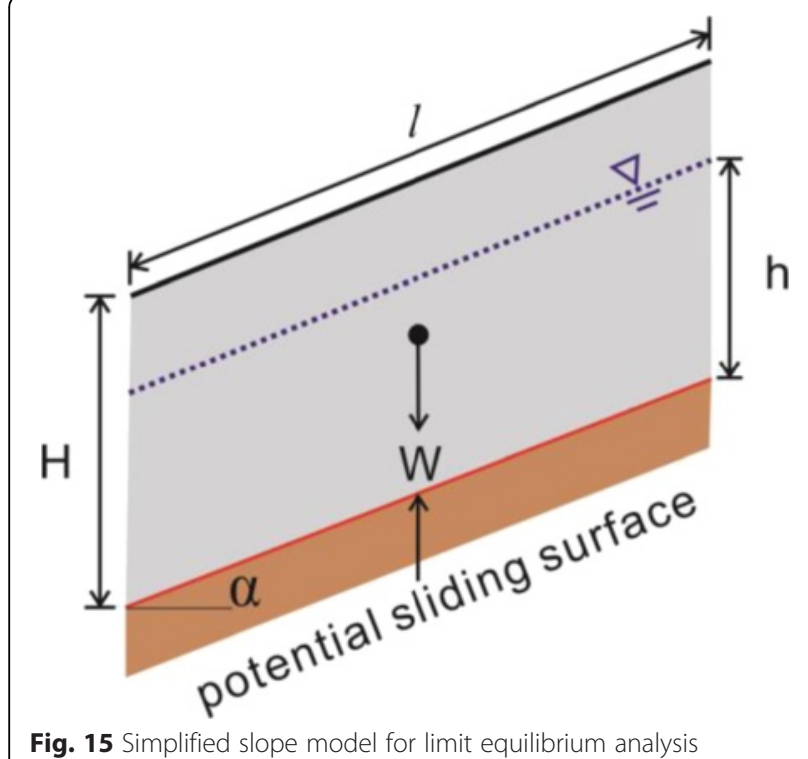

Fig. 15 Simplified slope model for limit equilibrium analysis

low. In contrast to Layers 2 and 4, Layer 3 and Layer 5 are fresh, dark gray pyroclastic-fall deposits with porous structure. Consequently, their permeability and water retention capability are quite high. With this sandwich panel structure, confined groundwater will be generated during continuous groundwater infiltration from the upper slopes. The results of triaxial tests using pore-water pressure control show that static liquefaction can occur in these porous pyroclastic-fall deposit layers. Piping holes were observed on the main scarp in the field, confirming the phenomenon of static liquefaction in porous pyroclastic-fall deposit layers (Wakai et al. 2014; Inagaki 2014; Ueno 2014).

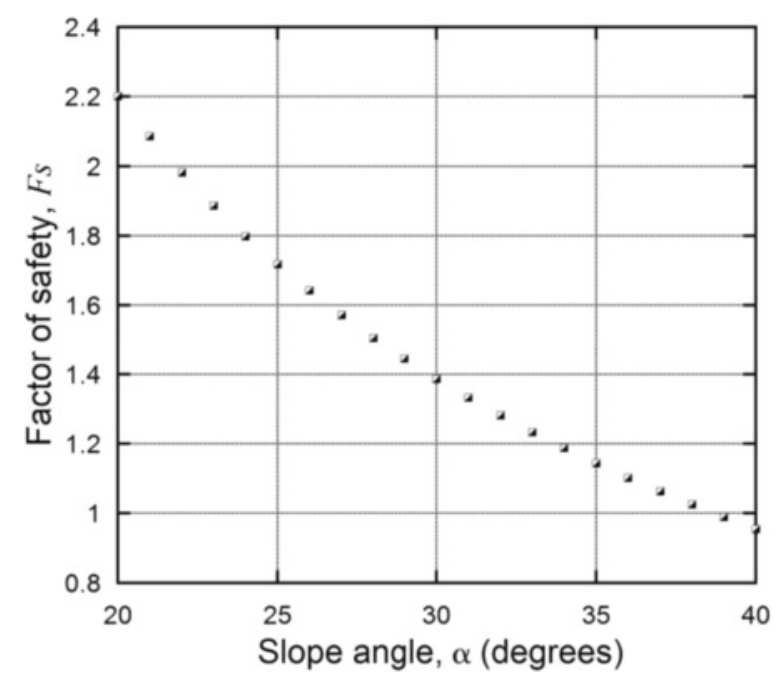

Fig. 16 The relationship between factor of safety $\left(F_{s}\right)$ and slope angle

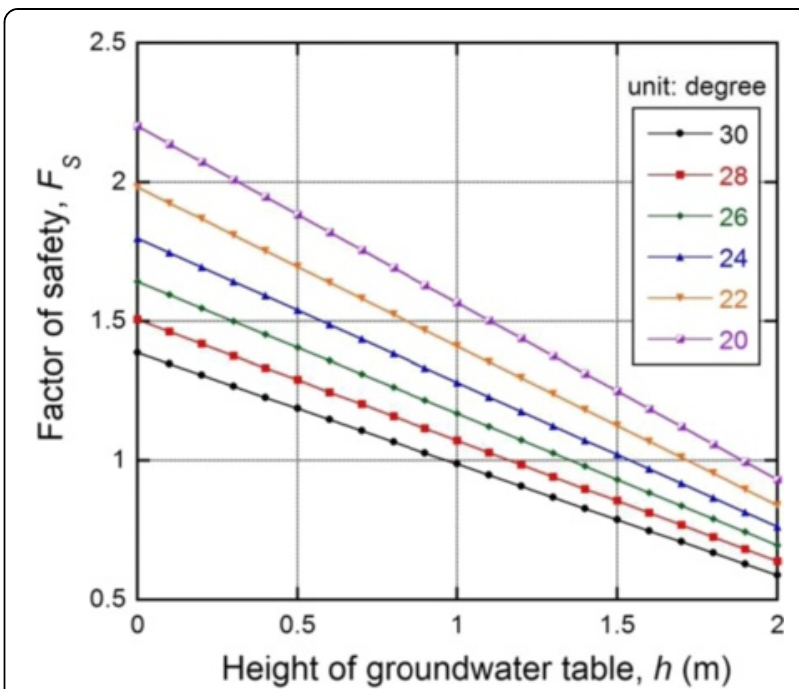

Fig. 17 The relationship of factor of safety $\left(F_{s}\right)$ with the height of the groundwater table and slope angle

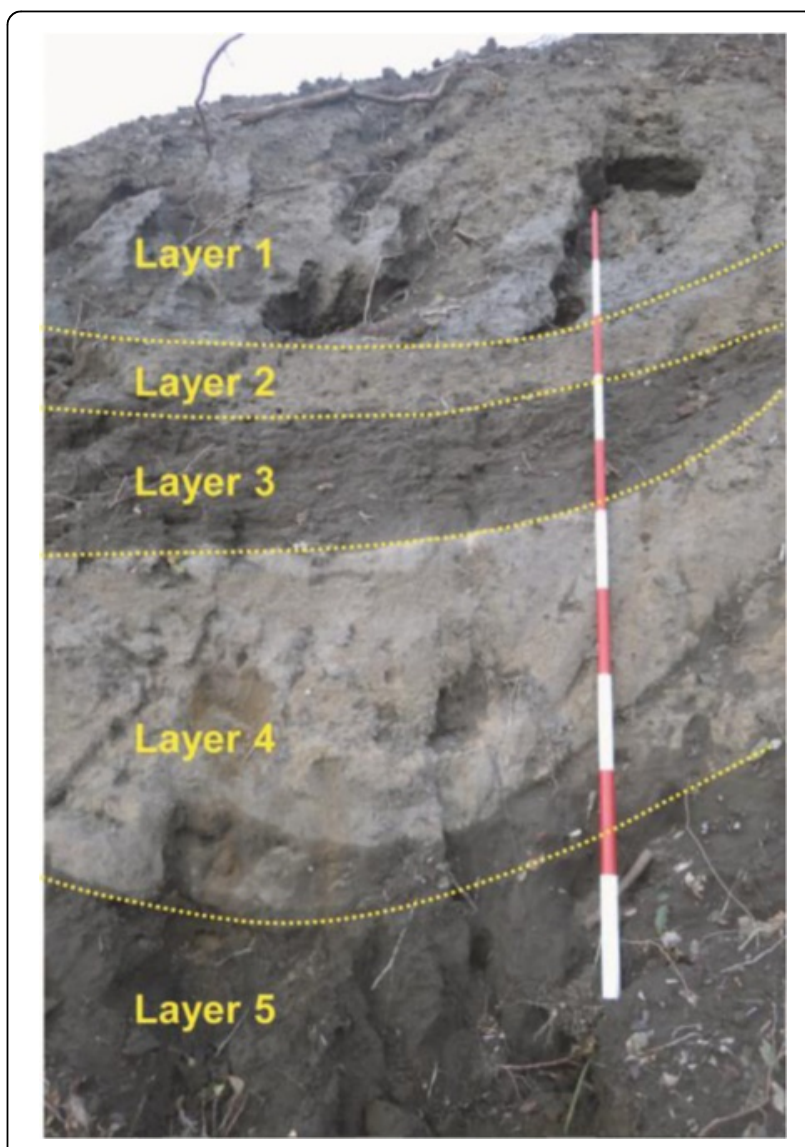

Fig. 18 Profile of pyroclastic-fall deposits (S2 in Figure 9) 


\section{Conclusions}

1. The effective strength of pyroclastic-fall deposits on the upper slope is quite high, and the effective internal friction angle is 38.7 degrees. Consequently, even though the slope is very steep (over 30 degrees), it can remain stable while in an unsaturated condition. Due to heavy rainfall and the porosity of the pyroclasticfall deposits, rainfall can quickly infiltrate into soil layer. Moreover, the interface above the underlying basalt will stop groundwater infiltration, acting as an impervious boundary. With increase of groundwater level, the effective strength of the porous soil will decrease. Finally, static liquefaction can be triggered, leading to the generation of shallow landslides on the upper slopes.

2. Slope cutting for road construction on the soft-hard slope structure (porous and shallow soil layer mantling the hard basalt layer) should be considered very carefully. Without any preventive measures, the upper layer soil can easily slide along the interface between the soft and hard layers.

3. The drainage system along the road, especially in areas of low terrain, provides an environment which easily gathered runoff water. An amount of water will continuously infiltrate into the slope below the road, leading to shallow landslides.

From the above, it is very important to evaluate the threshold rainfall for shallow landslide occurrences on Izu Oshima Island. This will be useful to build early warning systems to protect the local people during heavy rainfall events.

\section{Competing interests}

The authors declare that they have no competing interests.

\section{Authors' contributions}

All authors participated the field investigations. YH conducted the triaxial tests and drafted the manuscript. All authors read and approved the final manuscript

\section{Acknowledgements}

The authors would like to sincerely thank Dr. Barry Roser for his helpful and constructive comments to improve the manuscript. Valuable and constructive comments from anonymous reviewers are also appreciated. This work was financially supported by JSPS KAKENHI Grant Number A-2424106 for landslide dam failure prediction.

\section{Author details}

1Department of Geoscience, Shimane University, Matsue 690-8504, Japan. ${ }^{2}$ School of Environmental Design, Kanazawa University, Kanazawa 920-1192, Japan.

Received: 23 October 2014 Accepted: 5 May 2015

Published online: 09 June 2015

\section{References}

ASTM D2487-06 (2006) Standard Practice for Classification of Soils for Engineering Purposes (Unified Soil Classification System). ASTM International, West Conshohocken, PA, doi:10.1520/D2487-06
Disaster Prevention Division of Tokyo Metropolitan Government (TMG) (2014) Investigation report of Izu Oshima landslide triggered by Typhoon No. 26 in 2013. Sabo 115:7-11, In Japanese

Ikeya H (2014) Debris flow in Izu Oshima Island on October 16, 2013. Sabo 115:2-6 (In Japanese)

Inagaki H (2014) Mechanism of landslides occurrence. In: Investigation report of Izu Oshima landslide caused by Typhoon No. 26 in October 2013. P 74-77 (In Japanese)

Kawanabe Y (1998) Geological map of Izu Oshima volcano. Geological Map of Volcanoes 10, scale 1:25000. Geological Survey of Japan

Ministry of Land Infrastructure and Transport, Japan (2013) Report of the damage caused by heavy rainfall during the typhoon No. 26 (No. 16). http://www.bousai.go.jp/updates/h25typhoon26/pdf/h25typhoon26_16.pdf. Accessed 4 February 2014

National Research Institute for Earth Science and Disaster Prevention (NIED) (2013) Disaster in the history of Izu Oshima. http://dil.bosai.go.jp/disaster/ 2013H25T26/pdf/izuoshima_history.pdf. Accessed 22 January 2014

$\mathrm{Ng}$ C, Chiu A (2001) Behavior of a loosely compacted unsaturated volcanic soil. J Geotech Geoenviron 127(12):1027-1036

Sakurai M (2014) The past landslides. In: Investigation report of Izu Oshima landslide caused by Typhoon No. 26 in October 2013. P 9-10 (In Japanese)

Sakurai M, Disaster Research Team of Kanto Branch (2014) Landslide disaster of Izu-Oshima Island by typhoon No. 26 in 2013. Journal of the Japan Landslide Society 51(1):25-28, In Japanese

Skempton AW (1954) The Pore-Pressure Coefficients A and B. Geotechnique 4(4):143-147

Tokyo District Meteorological Observatory (TDMO) (2013) Quick report about Typhoon No. 26 in 2013. http://www.jma-net.go.jp/tokyo/sub_index/bosai/ disaster/ty1326/ty1326_tokyo.pdf. Accessed 4 February 2014

Ueno S (2014) Groundwater. In: Investigation report of Izu Oshima landslide caused by Typhoon No. 26 in October 2013. P 19 (In Japanese)

Wakai A, Uchimura T, Araki K, Inagaki H, Goto S (2014) Geotechnical characters of soil. In: Investigation report of Izu Oshima landslide caused by Typhoon No. 26 in October 2013. P 35-39 (In Japanese)

\section{Submit your manuscript to a SpringerOpen ${ }^{\odot}$ journal and benefit from:}

- Convenient online submission

Rigorous peer review

- Immediate publication on acceptance

- Open access: articles freely available online

- High visibility within the field

- Retaining the copyright to your article

Submit your next manuscript at $>$ springeropen.com 